\title{
Lagoon Seepage Testing Plan for the Specific Manufacturing Capability (SMC) Complex Sewage Lagoons at Idaho National Laboratory, Butte County, Idaho
}

\author{
Jestin Hurst
}

June 2018

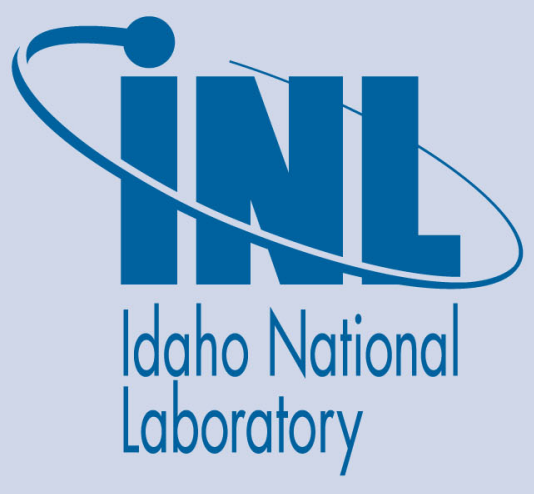

The INL is a U.S. Department of Energy National Laboratory operated by Battelle Energy Alliance 


\section{Lagoon Seepage Testing Plan for the Specific Manufacturing Capability (SMC) Complex Sewage Lagoons at Idaho National Laboratory, Butte County, Idaho \\ Jestin Hurst}

June 2018

Idaho National Laboratory Idaho Falls, Idaho 83415

http://www.inl.gov

Prepared for the

U.S. Department of Energy

Under DOE Idaho Operations Office

Contract DE-AC07-05ID14517 


\section{Lagoon Seepage Testing Plan}

for

\section{Specific Manufacturing Capability (SMC) Complex Sewage Lagoons}

at

\section{Idaho National Laboratory Butte County, Idaho}

Spring 2018
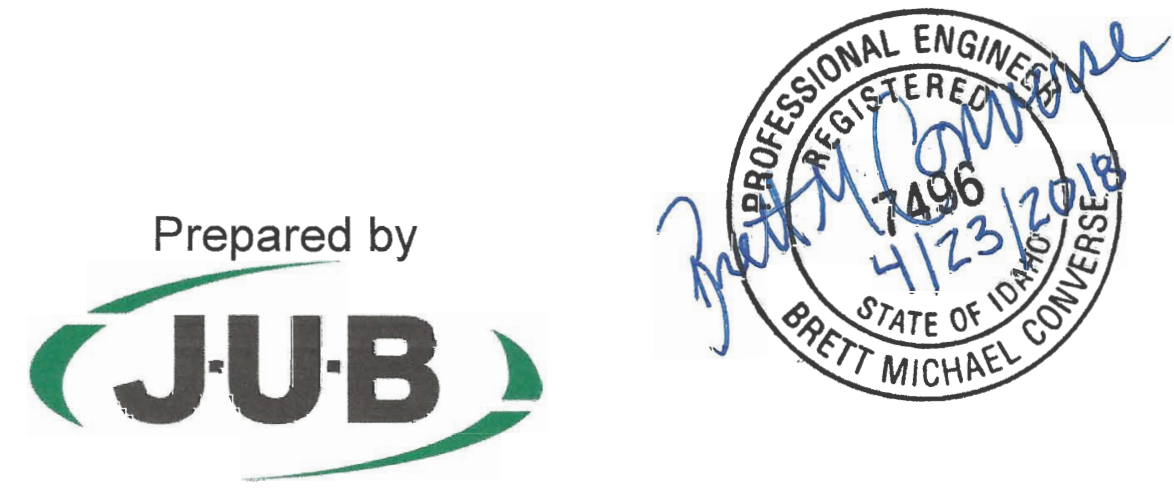

J"U.B ENGINEERS, INC.

677 South Woodruff Avenue

Idaho Falls, ID 83401

Phone - (208) 932-4486 



\section{Contents}

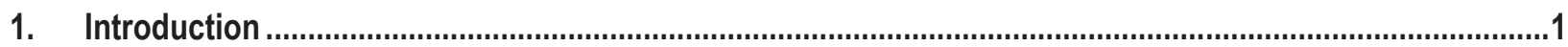

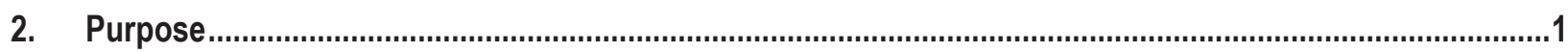

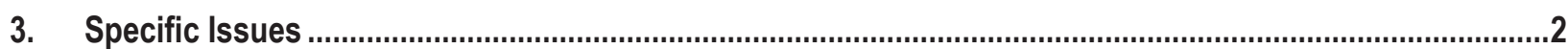

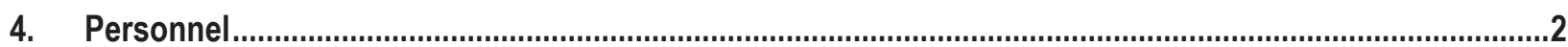

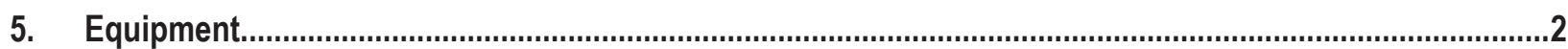

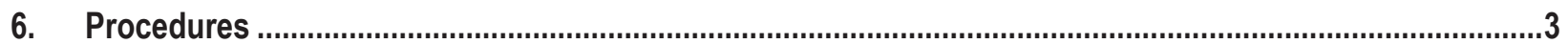

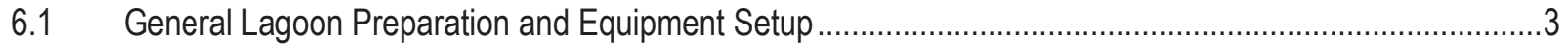

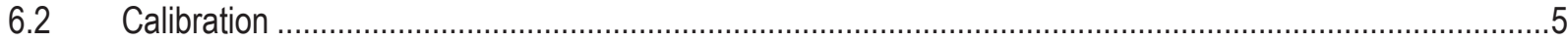

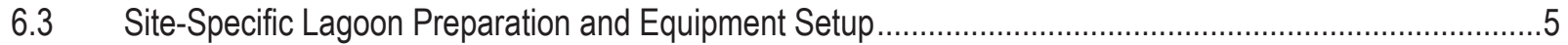

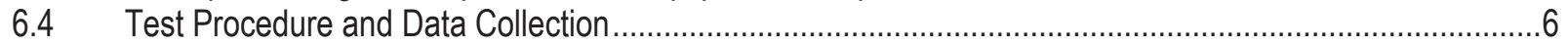

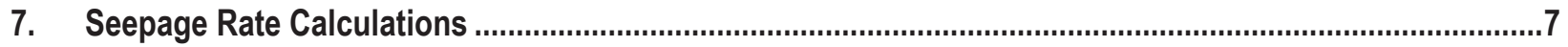

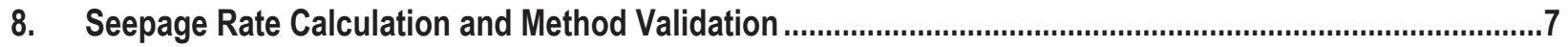

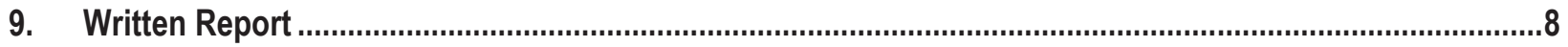

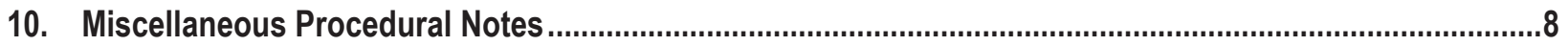

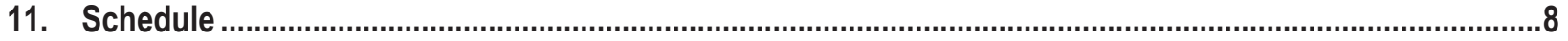

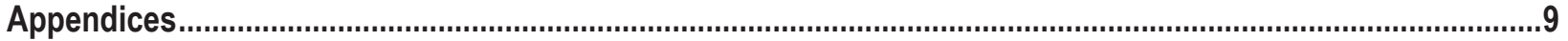

Appendix A Selected Drawings

Figure 1 - Vicinity Map

Figure 2 - SMC Area Map

Figure 3 - Overall Lagoon Site Plan

Figure 4 - Photo of Transfer Structure \#1

Appendix B Liquid Level Sensor Support Detail Appendix C Daily Log Sheet 



\section{Lagoon Seepage Testing Plan}

\section{for \\ Specific Manufacturing Capability (SMC) Complex Sewage Lagoons}

\section{Introduction}

Battelle Energy Alliance, LLC (BEA) operates the Specific Manufacturing Capability (SMC) Complex located in Butte County, Idaho at Idaho National Laboratory (INL). The SMC Complex has an existing wastewater system to collect and treat sanitary wastewater and boiler condensate water from the facility. The existing treatment facility consists of three cells: Cell \#1 has a surface area of 1.6 acres, Cell $\# 2$ has a surface area of 3.2 acres, and Cell \#3 has a surface area of 1.6 acres. If the three existing cells are to ever reach capacity, there is a stub out to the northeast for future expansion of the lagoons.

The Lagoons were installed in 1994, and were last tested in 2009. All three cells were within the acceptable limit, which at the time was one-quarter inch per day or less. The Idaho Department of Environmental Quality (IDEQ) is requiring that the seepage tests at SMC be repeated every 10 years.

The location and layout of the lagoons, transfer structures, outlet structures, yard piping, and flowcontrol and isolation valves and gates are shown in Figure 2, Figure 3 and Figure 4 in Appendix A.

The lagoons have the following characteristics:

Table 1-1: SMC Lagoons

\begin{tabular}{cccc}
$\begin{array}{c}\text { Lagoon } \\
\text { Cell \# }\end{array}$ & Year Constructed & $\begin{array}{c}\text { Maximum Water Depth } \\
\text { (ft-Approximate) }\end{array}$ & $\begin{array}{c}\text { Approximate Average Water } \\
\text { Surface Area } \\
\text { (acres) A }\end{array}$ \\
\hline $\mathbf{1}$ & 1994 & 6 & 1.6 \\
\hline $\mathbf{2}$ & 1994 & 6 & 3.2 \\
\hline A & 1994 & 6 & 1.6 \\
\hline
\end{tabular}

The lagoons will be tested to meet the requirements set forth in the Idaho Wastewater Rules (IDAPA 58.01.16). Since the lagoons were constructed prior to April 15, 2007, they will be tested to determine if the seepage rate is less than the allowable seepage rate of 0.25 inches per day.

\section{Purpose}

The lagoon seepage testing procedures are documented herein as required by the Wastewater Rules (IDAPA 58.01.16.493). The Wastewater Rules require that the procedure used for performing a seepage test be approved by IDEQ prior to conducting the seepage test. The procedures described herein are 
based on a seepage testing plan that was developed by J-U-B ENGINEERS, Inc. (J-U-B) and has been accepted by several IDEQ offices for lagoons in Idaho.

\section{Specific Issues}

Per IDEQ's guidance, lagoons must be tested when groundwater depth is below the bottom of the lagoons. The following depth to water level was collected from nearby monitoring wells:

Table 3-1: Nearby Well Depth to Water

\begin{tabular}{cccc} 
Well ID & Date Measured & Depth to Water $(\mathrm{ft})$ & Distance from Lagoon \\
\hline TANT-MON-A-001 & June 7, 2017 & 230.11 & 0.95 miles east \\
\hline USGS-007 & June 7, 2017 & 241.67 & $2 . .8$ miles south \\
\hline USGS-025 & Feb. 2018 & 320 & 2.3 miles northwest \\
\hline
\end{tabular}

Due to the extremely low groundwater in the area, it is assumed that the groundwater level will remain below the bottom of the lagoons during the lagoon seepage testing.

Each lagoon cell will be tested for seepage independently. Should insufficient valving or gating not allow a lagoon cell to be isolated to the degree necessary for seepage testing, the lagoon cell will be hydraulically connected to another cell. Once the water level in the connected lagoons equalizes, the seepage test will be performed for the connected lagoon cells, which will determine the seepage rate for both lagoons. The SMC lagoons are designed to operate sufficiently with any individual cell offline or with Cells 1 and 3 offline at the same time.

\section{Personnel}

Jestin Hurst, P.E., J-U-B, will be the Idaho Licensed Professional Engineer responsible for seepage testing of the lagoons. Rob Lane, Jordan Parker, other J-U-B employees, and BEA employees will assist Jestin during setup and performance of the daily inspections.

\section{Equipment}

The following equipment will be used for lagoon seepage testing:

1. Precipitation Gauge - A TE525-series tipping bucket rain gauge manufactured by Texas Electronics able to measure in 0.01 -inch increments. The momentary switch closure is counted by the pulse-counting circuitry of Campbell Scientific data loggers.

2. Air Temperature Sensor - Campbell Scientific 107-L6 temperature sensor with 6-gill plate solar radiation shield.

3. Water Temperature Sensor - Campbell Scientific 107-L20 temperature sensor.

4. Wind Speed and Direction - Campbell Scientific 03002 Wind Sentry set with a 3-cup anemometer and wind vane. 
5. Liquid Level Sensor (2) - GeoKon Model 4675LV, vibrating wire force transducer for water level monitoring with a full-scale sensor range from 0 to 6 inches and an accuracy of $\pm 0.1 \%$ of full scale.

6. Power Supply $-12 \mathrm{~V}$ battery with 10 watt solar panel.

7. Wooden Instrument Box and Supports

8. Data Logger - Campbell Scientific CR 850 data logger and support software.

9. Class A evaporation pan with pan stilling well, situated on a level base constructed from wood. The evaporation pan will be a 4-foot-diameter stainless steel pan. The stilling well will be a 4inch-diameter PVC tube attached to a galvanized steel tube with a triangular leveling base.

\section{Procedures}

The following testing and measuring methods will be used:

\subsection{General Lagoon Preparation and Equipment Setup}

The general preparation and equipment setup steps are as follows:

1. Isolate the sewage lagoon pond to be tested.

a. This step is unique to each lagoon. Refer to Section 6.3 for site-specific steps.

2. Fill the lagoon to be tested to the design operating depth, or the depth at which the lagoon is to be tested, prior to the start of the seepage test and wait for the lagoon to stabilize. If two to four weeks pass without reaching stabilization ${ }^{1}$, the client will be consulted before testing will begin. If the lagoon is not tested at the maximum design depth, the lagoon will only be allowed to operated up to the depth at which it was tested. If additional operating depth is needed, the lagoon will have to be seepage tested at that depth.

3. Identify a setup location.

4. Install a temporary fence and protective barrier around the setup location to protect the equipment from animals and guard against vandalism. This fence will consist of temporary construction fencing fabric attached to tubular markers or poles weighted sufficiently to hold the fence in place and protect the equipment. Prior to testing, fishing line will be suspended above the evaporation pan at approximately 12 -inch spacing. The fishing line will likely be strung between the fencing used to enclose the equipment. Flagging or ribbon will be attached to the fishing line in locations where shadows will not be cast on the water.

5. Set up the evaporation pan on a level wood base and supported approximately 6 inches above the ground within the setup area. Fill to within 2 inches of the top with clean water. Check if the pan is still level after filling with water to ensure the pan has not moved.

a. The evaporation pan will be located on a level surface as close to the lagoon as possible, and not near sun or wind blocks (building or trees).

b. The pan will be leveled using shims.

\footnotetext{
${ }^{1}$ Stabilization is reached when lagoon levels do not drop more than 0.5 inches per day based on visual observation.
} 
c. The pan stilling well will be anchored in the pan and not moved once the test period begins.

d. Initial water level in the pan will be approximately 2 inches below the lip.

e. Fresh water will be used to fill the pan and to add water to the pan if necessary.

${ }^{1}$ For Saturdays, Sundays, and holidays, it may not be possible to perform the field check of the equipment. For days when a field check is not performed, an automatic camera will be utilized to photograph the site numerous times throughout the day. Those photos will be reviewed, along with the data collected on the following day, to verify that the data collected is viable. Any discrepancies in the data or issues observed in the photos will be reported in the final report.

f. Under no circumstances should the pan or instrument shelter be placed on a concrete slab or pedestal, over asphalt, or on crushed rock

6. Set up the wooden instrument box and attach the following equipment:
a. Solar panel
b. Rain gauge
c. Wind anemometer
d. Air temperature sensor and Gill shield
e. Air temperature sensor in the lagoon stilling well
f. Data logger weatherproof enclosure

7. Set up the liquid level sensor in the lagoon (must be mounted vertically). Refer to Appendix B for a general detail of mounting the liquid level sensor in a concrete transfer structure or control structure.

a. This step is unique for each lagoon to be tested. Refer to Section 6.3 for site-specific steps.

b. Attach the liquid level sensor to the jack screw (length sufficient to reach 3 feet below the water surface).

c. Set two beams across the supporting structure. Check that the beams are level and secure; use shims to adjust them as needed.

d. Locate the jack screw plate between the two beams.

e. Submerge the liquid level sensor 5 inches below the water surface.

f. Turn the jack nut until it contacts the plate.

g. Turn the locking nut tight against the plate from the bottom.

h. Secure the plate to the beams with "C-clamps."

i. Mark position of equipment so it can be relocated if accidentally moved.

i. If the level sensor support is accidentally moved or bumped, relocate the support in the original location.

ii. Make a note in the daily log of the time the support was bumped, moved, and/or relocated. 
j. Verify that nothing is placed on top of the wire and that it is free of kinks and extreme bends during the test. This is necessary to protect the air tubes located inside the level sensor wires.

8. Set up the liquid level sensor within the 4-inch PVC stilling well in the evaporation pan (must be mounted vertically). Place stilling well so liquid level sensor is in the center of the evaporation pan.

a. Verify that nothing is placed on top of the wire and that it is free of kinks and extreme bends during the test. This is necessary to protect the air tubes located inside the level sensor wires.

9. Set up the battery.

10. Set up the data logger.

11. Connect equipment to the data logger.

12. Record the setup with photographs.

\subsection{Calibration}

The liquid level sensors are calibrated by the manufacturer.

\subsection{Site-Specific Lagoon Preparation and Equipment Setup}

The site specific lagoon preparation and equipment setups are as follows (see Appendix $\mathbf{A}$ for referenced figures):

1. Fill the lagoon to the test level, if necessary.

2. Isolate the lagoon cell to be tested. Note that the valve/gate operations described below are not listed in any particular order and should be coordinated and performed in the field by the Sewage Treatment Plant operator. Field modifications to the suggested plan may be needed to respond to site specific conditions. In order to completely isolate each lagoon cell, it will be necessary that all valves and plugs are water tight.

a. To isolate Lagoon Cell \#1 (see Figure $\mathbf{3}$ and Figure $\mathbf{4}$ in Appendix A):

i. Block influent in Inlet Structure \#1 by closing the valve leading to Cell \#1.

ii. Close the valve to Cell \#2 and Cell \#3 at Transfer Structure \#1.

iii. Adjust other valves/gates/plates as necessary for operation.

b. To isolate Lagoon Cell \#2 (see Figure 3 and Figure 4 in Appendix A):

i. Block influent in Inlet Structure \#1 by closing the valve leading to Cell \#2.

ii. Close the valve to Cell \#1 and Cell \#3 at Transfer Structure \#1.

iii. Adjust other valves/gates/plates as necessary for operation.

c. To isolate Lagoon Cell \#3 (see Figure 3 and Figure 4 in Appendix A):

i. Block influent in Inlet Structure \#2 by closing the valve leading to Cell \#3.

ii. Close the valve to Cell \#1 and Cell \#2 at Transfer Structure \#1. 
iii. Adjust other valves/gates/plates as necessary for operation.

3. Equipment setup:

a. Set up the lagoon level sensor and support beams on the hydraulically connected transfer structure or manhole.

i. Cell \#1: Mount level sensor in Transfer Structure \#1.

ii. Cell \#2: Mount level sensor in Transfer Structure \#1.

iii. Cell \#3: Mount level sensor in Transfer Structure \#1.

b. Follow the general setup steps above to finish installing the lagoon level sensor.

c. Set up the remaining testing equipment nearby.

\subsection{Test Procedure and Data Collection}

1. In addition to the date and time, measurements from the following instruments will be recorded via the data logger every 4 minutes:
a. Rain gauge, inches of rain
b. Evaporation pan surface water temperature, degrees $\mathrm{F}$
c. Evaporation pan water surface elevation, inches above level sensor
d. Lagoon water surface elevation
e. Air temperature, degrees $\mathrm{F}$
f. Wind speed, mph
g. Wind direction, Azimuth degrees

2. Record measurements for approximately 120 hours, or less if consistency of data allows for a shorter duration.

3. Perform the following checks at approximately the same time each day $^{2}$ (refer to Appendix $\mathbf{C}$ for an example Daily Log Sheet):

a. Water level in the evaporation pan:

i. If the water level has dropped lower than 3 inches below the rim, add clean water to bring the liquid level up to 2 inches below the rim.

ii. Make a note in the log that water was added. The added water will be reflected in the subsequent level sensor readings.

iii. The change in liquid level sensor readings (inches) immediately after adding water will be subtracted from subsequent data recorded by the data logger to determine the overall change in pan surface elevation $\left(E_{\mathrm{pano}}-E_{\mathrm{pan} n}\right)$ at the end of the test.

\footnotetext{
${ }^{2}$ For Saturdays, Sundays, and holidays, it may not be possible to perform the field check of the equipment. For days when a field check is not performed, an automatic camera will be utilized to photograph the site numerous times throughout the day. Those photos will be reviewed, along with the data collected on the following day, to verify that the data collected is viable. Any discrepancies in the data or issues observed in the photos will be reported in the final report.
} 
b. Water level in lagoon:

i. If the water level has dropped more than 3 inches, rotate the jack-nut plate until the liquid level sensor is submerged approximately 5 inches.

ii. Make a note in the log that the liquid level sensor was lowered. The lowered liquid level sensor will be reflected in subsequent liquid level sensor readings.

iii. The change in liquid level sensor readings (inches) immediately after lowering the level sensor will be subtracted from subsequent data recorded by the data logger to determine the overall change in lagoon surface elevation $\left(E_{s 0}-E_{s n}\right)$ at the end of the test.

c. Check all equipment for signs of disturbance.

4. Download data and review/verify on the third day at the latest, or a daily basis:

a. Adjust test if necessary and document on daily log sheets as needed.

5. Download data after 120 hours and review/verify data to determine patterns:

a. Validate the test. If the test is valid, the test may end.

b. If time allows, additional measurements will be collected to provide extra data in case data has to be discarded due to unforeseen issues (wind, heavy rain, lightning, wildlife, failed isolation). If insufficient data is collected in the 120 hours to validate the test, the situation will be reviewed with the Owner and the Owner will decide whether to continue collecting additional data or end the test. Ending the test without sufficient data will result in a nonvalid test.

\section{Seepage Rate Calculations}

The data will be entered into the IDEQ-provided Excel file that has been modified to accommodate J-U-B's data management scheme. The seepage rate will be calculated using the equations in the IDEQ spreadsheet.

\section{Seepage Rate Calculation and Method Validation}

J-U-B will use Visual Sample Plan software to calculate the number of discrete events needed to gain confidence in the dataset ( $95 \%$ confidence, alpha \& beta=5\%). If the number of sample events obtained is equal to or greater than the number needed to have confidence in the test, the results are valid and the seepage test can end. If additional sample events are needed, the test should be continued until the number of discrete events are reached. It is our understanding that DEQ will use a multi-metric approach to evaluate the seepage test as shown in the following Table 8-1.

Table 8-1: Validity Approach

\begin{tabular}{lll}
\hline Parameter & Type & Description and Objective \\
\hline Compliance & Objective & $\begin{array}{l}\text { Assess whether the anticipated average seepage rate exceeds the regulatory } \\
\text { limit }(0.125 \text { or } 0.25 \text { inches per day) and screen to a first tier compliance category } \\
\text { status (compliant/non-compliant). }\end{array}$ \\
& Objective & $\begin{array}{l}\text { Determine if a sufficient number of calculated seepage rates exist to make a } \\
\text { valid decision for compliance determination. }\end{array}$
\end{tabular}




\begin{tabular}{|c|c|c|}
\hline Category & Objective & $\begin{array}{l}\text { Evaluate the impact of the errors/uncertainties on category assignment; make a } \\
\text { determination whether the lagoon status is Category } 1,2,3 \text {, or } 4 \text { (second tier) }\end{array}$ \\
\hline Consistency & $\begin{array}{l}\text { Quantitative with } \\
\text { Arbitrary Limits }\end{array}$ & Determine if the most recent seepage rate conforms to the $\pm 20 \%$ standard. \\
\hline Comparability & $\begin{array}{l}\text { Personal Judgment/ } \\
\quad \text { Subjective }\end{array}$ & $\begin{array}{l}\text { Evaluate the degree to which levels in the lagoon and evaporative pan compare. } \\
\text { Conclusion is based on the time series plot in the } \underline{D E Q} \text { spreadsheet. }\end{array}$ \\
\hline \multirow[t]{2}{*}{ Data Sufficiency } & $\begin{array}{l}\text { Personal Judgment/ } \\
\text { Subjective }\end{array}$ & $\begin{array}{l}\text { Determine if the minimum number of data/measurements obtained during the } \\
\text { course of the testing were obtained and }\end{array}$ \\
\hline & & Determine if sufficient hook gauge measurements were obtained. \\
\hline Data Quality & $\begin{array}{l}\text { Personal Judgment/ } \\
\quad \text { Subjective }\end{array}$ & $\begin{array}{l}\text { Determine whether data were collected at the proper time/intervals and whether } \\
\text { appropriate procedures and methods were employed. }\end{array}$ \\
\hline
\end{tabular}

This seepage testing procedure and methodology will provide DEQ with sufficient data to evaluate the seepage test results.

\section{Written Report}

A written report will be provided to IDEQ summarizing the data collected and the results.

\section{Miscellaneous Procedural Notes}

1. Data collected will be documented and provided to IDEQ in a written report.

2. Equipment manufacturer specification and calibration details will be provided to IDEQ upon request.

3. Photos will be taken of the setup and provided in the written report, including photos of the site before and after the test, evaporative pan set up, and protective measures.

4. Equipment will be protected from animals, recreational activities, and vandalism.

5. Liquid level sensors will be installed in existing lagoon transfer structures or manholes because the existing structure is more stable than trying to set up the equipment to collect data directly from the pond. It is also safer, and reduces the risk of falling or damaging equipment.

6. By monitoring wind speed and direction, wind effects will be determined, and impacts that the wind may have on the lagoon surface elevation will be correlated. If wind impacts are observed, data collected when the wind effects are apparent will not be used in the seepage analysis.

7. Data collected during freezing conditions will not be used to estimate evaporation rates from the lagoon. Data collected when ice is present within the pan or on the lagoon will not be used. The daily log sheet includes a check for ice on the lagoon and in the pan.

\section{Schedule}

Seepage testing of the sewage lagoons is anticipated to be completed within the following schedule (depending upon weather conditions and IDEQ approval):

$>$ Seepage testing will begin in June 2018

$>$ Seepage testing will be completed in June or July 2018 
$>$ Written report submitted to IDEQ following the seepage testing, by August 2018

\section{Appendices}

Appendix A - Selected Drawings

Figure 1 - Vicinity Map

Figure 2 - Area Map

Figure 3 - Overall Lagoon Site Plan

Figure 4 - Photo of Transfer Structure

Appendix B - Liquid Level Sensor Support Detail

Appendix C - Daily Log Sheet 


\section{Appendix A}

\section{Selected Drawings}

Figure 1 - Vicinity Map

Figure 2 - SMC Area Map

Figure 3 - Overall Lagoon Site Plan

(Drawing provided by Client - Drawing Number AR-9301 Sheet C-2)

Figure 4 - Photo of Transfer Structure \#1 


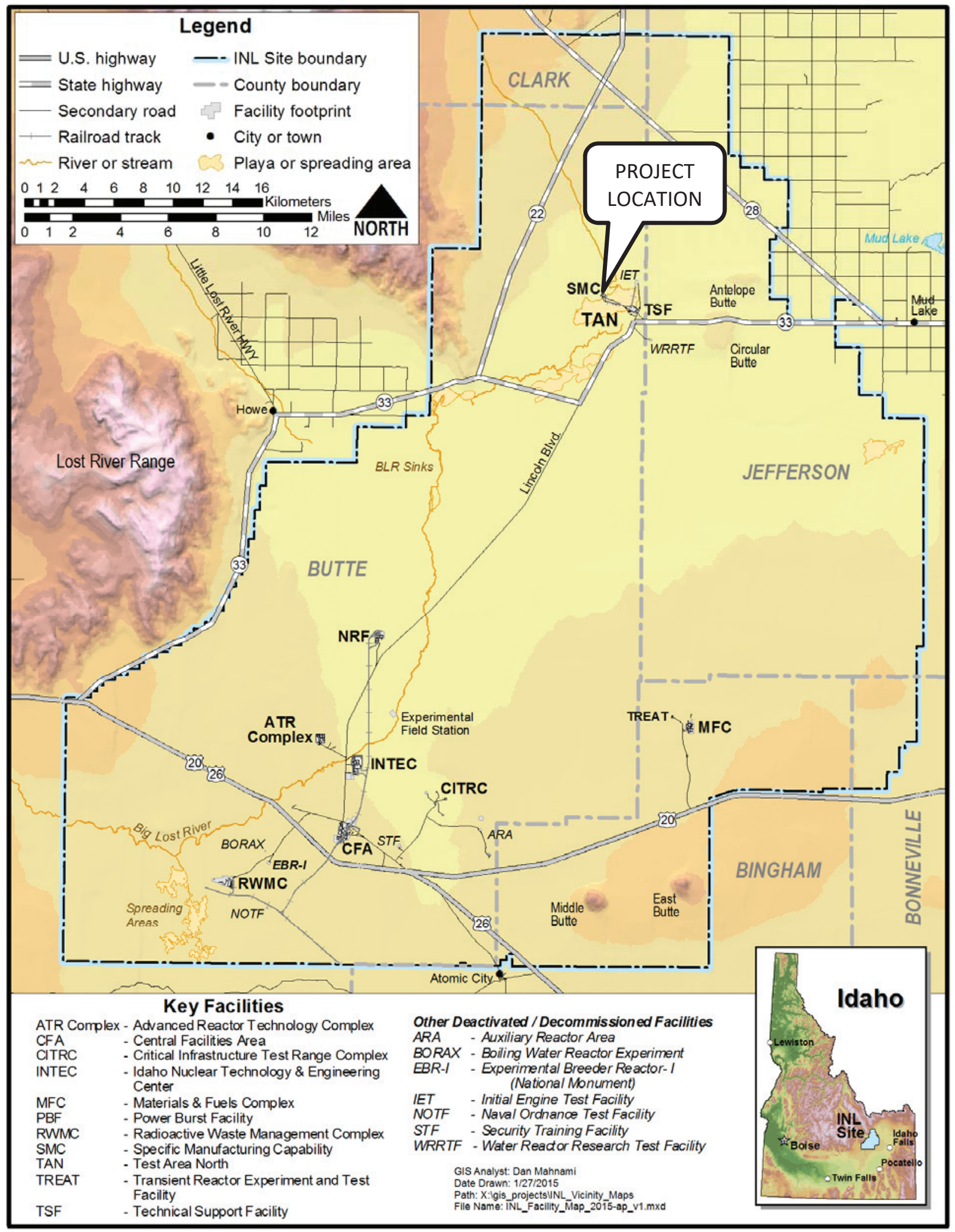

Figure 1 - Vicinity Map 


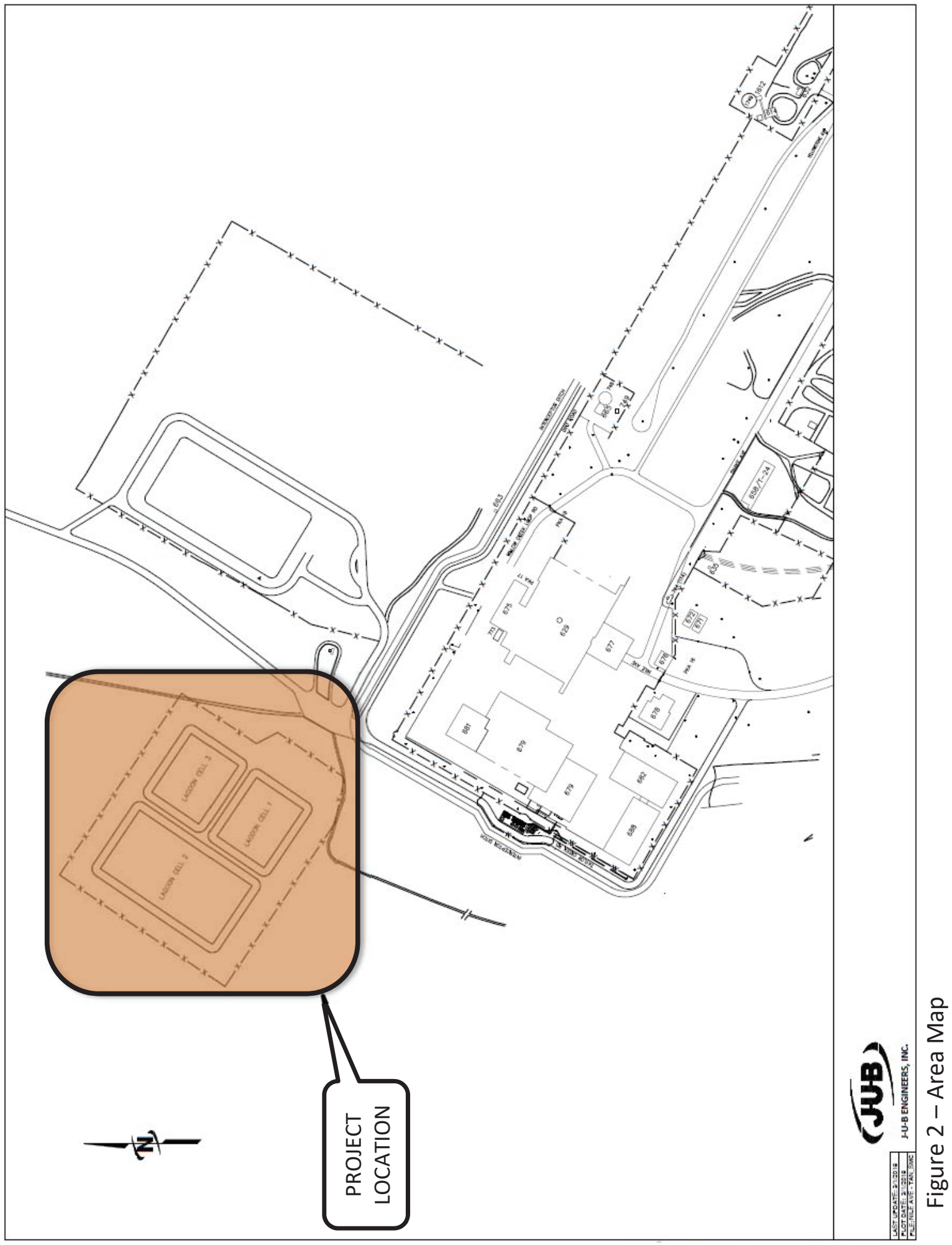




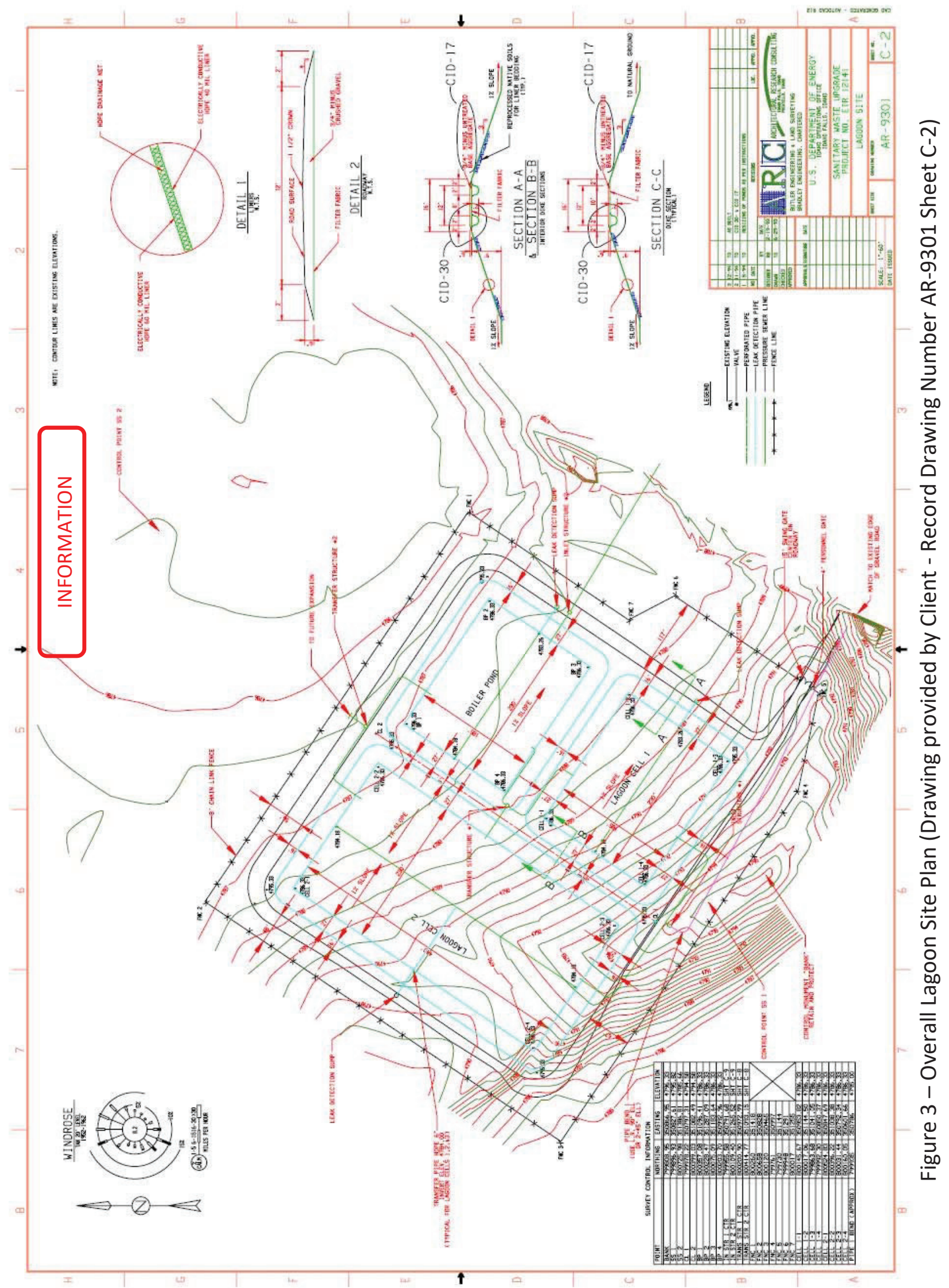




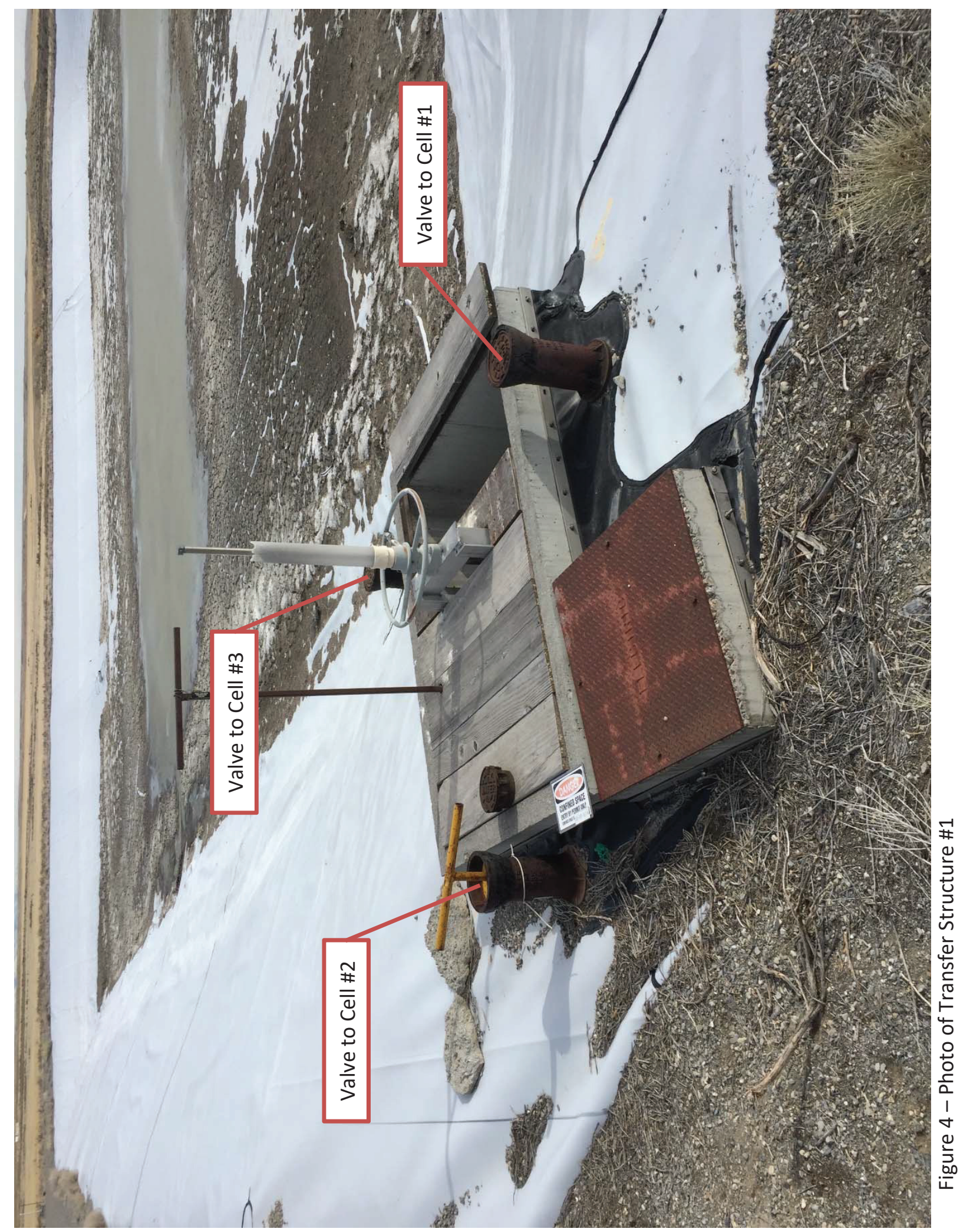




\section{Appendix B}

\section{Liquid Level Sensor Support Detail}




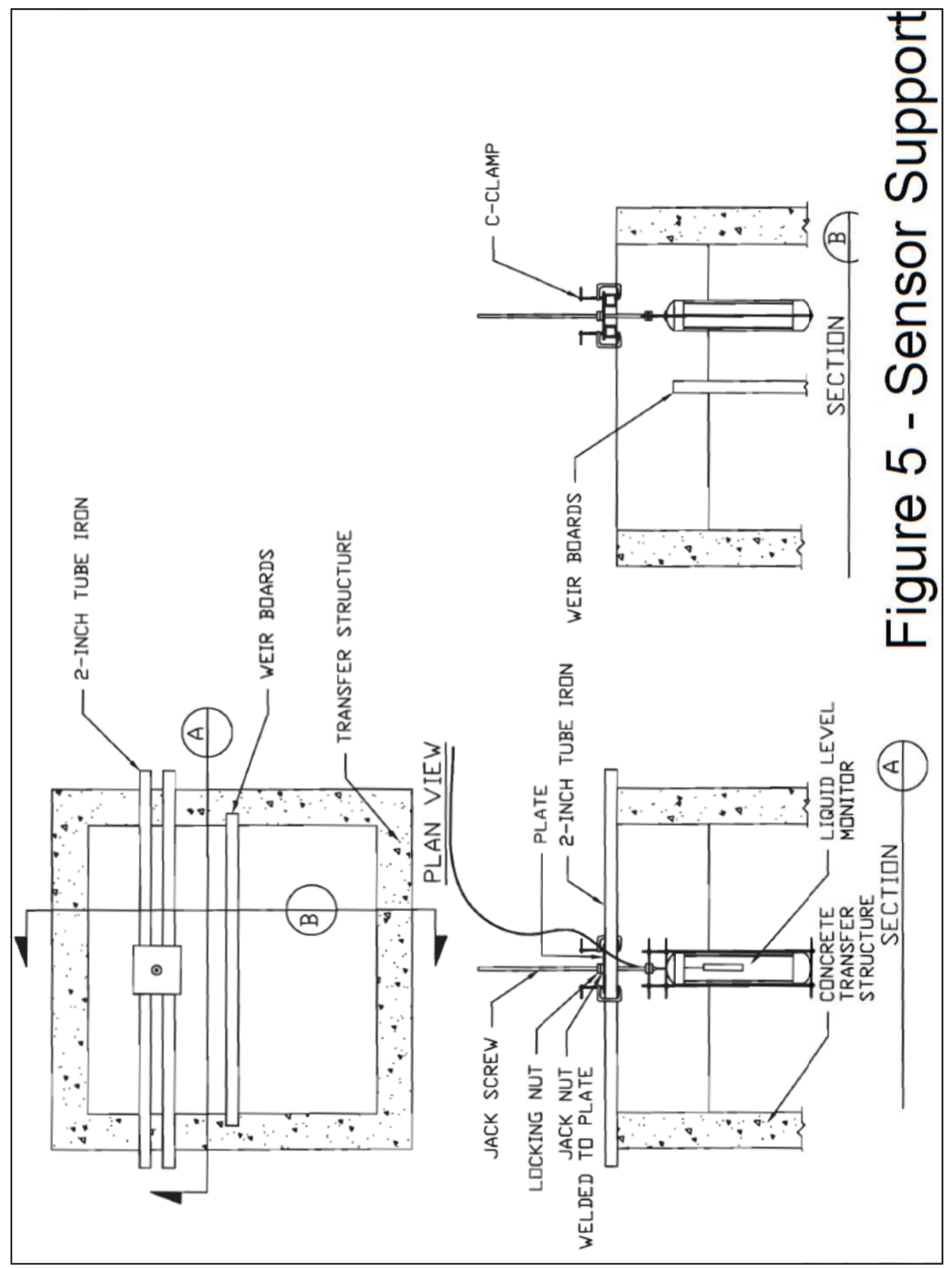




\section{Appendix C}

\section{Daily Log Sheet}




\section{Daily Log Sheet}

Lagoon

Day/Date

Time

Performer (name and signature)

BEA QA/QC

1. Water surface in Pan

a. Is water surface within three inches from the top?

b. Was Water Added

i. Date

ii. Time

c. Is ice present? No Yes Note time when ice is absent

2. Water surface in Lagoon

a. Is liquid level within range of the buoy?

b. Was level sensor lowered

i. Date

ii. Time

c. Is ice present? No Yes Note time when ice is absent

3. Check Equipment
a. Fence
b. Wooden instrument box
c. Solar panel
d. Battery
e. Weather proof enclosure
f. Rain gauge
g. Wind anemometer
h. Wind vane
i. Air temperature sensor and gill shield
j. Air temperature sensor
k. Water temperature sensor
I. Lagoon liquid level sensor
m. Pan liquid level sensor
n. Check air pressure in inflatable plugs (if applicable)

4. Other Adjustments 